\title{
JUURNAL.RU
}

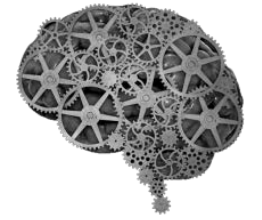

COMPANY GROUP "INTELLEKT"

\author{
Воробьева О.В., Любовцева Л.А. \\ Чувашский государственный университет им. И.Н. Ульянова \\ Чебоксары, Россия
}

doi: 10.18411/lj2016-6-1-04

\section{Морфофункциональные изменения в структурах костного мозга после аутопересадки костного мозга}

В последнее время для лечения онкологических, гематологических заболеваний применяется трансплантация костного мозга [1], целью которой является восстановление кроветворения больного после облучения. Одновременно с максимальным уничтожением опухолевой ткани при трансплантации костного мозга подавляется и иммунитет больного.

Развитие иммунной реакции в организме сопровождается значительными изменениями содержания нейроаминов в тканях [2,3]. Поскольку процессы клеточного созревания и дифференцировки, обеспечивающие иммунитет $[7,8]$ начинаются в костном мозге, значительный интерес представляет исследование реакции аминосодержащих структур при аутопересадке костного мозга.

Цель исследования - изучить содержание гранулярных люминесцирующих и тучных клеток, содержащие нейроамины, в структурах костного мозга после аутогенной трансплантации в разные сроки.

\section{Материал и методы исследования}

Работа была выполнена на 40 мышах: 1 группа — интактные мыши (n=20). 2 группе проводили аутотрансплантацию $(\mathrm{n}=20)$ - в/в ведение суспензии $(0,1$ мл костного мозга перемешивали с физиологическим раствором) и в хвостовую вену этой же мыши. Число клеток в 1 мл суспензии было равно 2,1* $10^{8}$. 


\section{Методы исследования:}

1. Для избирательного выявления катехоламинов и серотонина применялся люминесцентно - гистохимический метод Фалька- Хилларпа (1969).

2. Иммуногистохимическое исследование с антителами к нейроспецифической енолазе (Производство Daco, USA). Ядра клеток докрашивались гематоксилином. Подсчитывалось количество иммуноположительных клеток на квадратный миллиметр.

\section{Результаты исследования и их обсуждение}

Через 15 мин от начала опыта в мазках костного мозга увеличивается число ГЛК до 8,2 при норме 3-4 клетки и тучных клеток до 4-х вместо 1-2. Содержание катехоламинов и серотонина в них повысилось в два раза.

Через 40 минут число ГЛК остается повышенным до 5 - 7, содержащие повышенное количество катехоламинов, серотонина.

Две разновидности гранулярных клеток выявлено: одни мелкие с компактно расположенными гранулами (макрофаги), другие - крупные с рыхло расположенными разнокалиберными гранулами, в которых люминесцируют 2 3 гранулы. Остальные гранулы перестают люминесцировать, т.е. моноамины выходят из гранул, вследствие чего наблюдается увеличение диффузности свечения межклеточных пространств.

Число тучных клеток снижено до 16 на весь препарат, однако содержание катехоламинов и серотонина в них повысилось в два раза. Нервные волокна располагаются в виде петель, около которых находятся гранулярные и тучные клетки. Выявляются две группы лимфоцитов: с ярко люминесцирующими и тусклыми ядрами. У юных и палочкоядерных нейтрофилов начинают слабо люминесцировать ядра. Возможно, все это говорит об активации иммунной реакции. Остальные гемопоэтические клетки практически не люминесцируют, т.е. не содержат свободных моноаминов. 
Увеличивается содержание нейроспецифической енолазы в тучных клетках. Предположительно, произошло увеличение выявляемости клеток, принадлежащих к АПУД - системе.

Часть тучных клеток становятся высоко сульфатированными. Нейроамины накапливаются в межклеточном веществе. Вследствие чего увеличивается число митозов, образуются шаровидные скопления морфологически одинаковых клеток, по периферии которых располагаются ГЛК.

Анализируя полученные данные, можно заключить, что при аутогенной трансплантации костного мозга в препаратах костного мозга мышей снижается число тучных и повышается количество гранулярных люминесцирующих клеток, а в них содержание биогенных аминов. Однако истощается запас этих веществ в каждой отдельно взятой клетке. Увеличивается люминесценция межклеточного вещества. Наблюдается активация иммунных процессов, вследствие увеличения нейроаминов в межклеточном пространстве. Увеличение нейроаминов происходит в результате выхода этих веществ из ГЛК и дегранулирующих ТК. По нашим и литературным данным, повышение содержания катехоламинов приводит к увеличению бластных форм клеток, а увеличение содержания серотонина- к ускоренной дифференцировке.

\section{Выводы:}

1. При аутогенной пересадке костного мозга в препаратах костного мозга увеличивается число ГЛК с уменьшением количества гранул в них и уменьшением числа ТК вследствие их дегрануляции.

2. Выявляются группы ярко люминесцирующих митотически делящихся клеток.

3. Увеличивается содержание нейроаминов в межклеточном веществе.

4. Произошло увеличение выявляемости клеток, принадлежащих к АПУД - системе. 


\section{Литература:}

1. Савченко В.Г. Трансплантация костного мозга в онкогематологии// Клиническая онкогематология. Фундаментальные исследования и клиническая практика. - 2010. - Т. 3, №4. - С. 478-479.

2. Карноухов Н.А. Люминесцентные параметры ядерных клеток крови в процессе иммунного ответа организма// Биофизика. - 1984. - Т29, №2. - С. 276-279.

3. Любовцева Л.А., Любовцева Е.В. Биоаминсодержащие структуры костного мозга при системных заболеваниях крови// Морфология. - 2012.№ 3.- C. 95-96. 